\title{
Which ones are more important: characteristics or complexities? A study of the disclosure in local government financial reports
}

\author{
Hari Purnama, Putri Alfina \\ Universitas PGRI Yogyakarta \\ haripurnama@upy.ac.id, putrialfina007@gmail.com
}

\begin{abstract}
Local Government Financial Report (LGFR) is one form of local government transparency in financial reporting for a period. The study aims to determine the effect of characteristics as proxied by the assets and size of local government, and complexity as proxied by the number of LGFRs and size of Legislature on the extent of financial report disclosure of local government. The data employed in this study are Local Government Financial Reports from 9 Municipal Governments and 18 Regencial Governments in West Java for the period 2014-2017. The results of this study suggest that the asset and size of local government have a positive effect on the degree of financial report disclosure of local government. On the other hand, the number of LGFR and legislature size has no effect on financial report disclosure of local government.
\end{abstract}

Keywords: local government asset; local governement size; number of LGFR; legislature size; financial report disclosure

\section{Background}

Good governance is a procedure adopted in the government agencies to create clean, transparent, and accountable governance. Good governance is closely related to how governments manage and implement their autonomy in their respective region (Maulana \& Handayani, 2015). Government as the party that runs the administration, development, and public services is required to be transparent in financial management in order to build a clean government (Setyaningrum \& Syafitri, 2012). One appropriate effort to increase transparency is to prepare Local Government Financial Reports based on Government Accounting Standards (GAS). Government accounting standards have a role and legal force in improving the quality of government financial reports (Suhardjanto \& Yulianingtyas, 2011).

Financial report disclosures can be classified into 2 categories: mandatory disclosure and voluntary disclosure (Suhardjanto \& Yulianingtyas, 2011). In Indonesia, local government financial reports had average mandatory disclosures of $22 \%, 51,56 \%$ (Suhardjanto \& Lesmana, 2010), and 55\% (Budiarto \& Indarti, 2019). This suggests that local governments have not fully disclose the mandatory items in their financial reports. This phenomenon deserves further analysis to identify the factors that increase the mandatory disclosure in local government financial reports, especially in West Java.

Government Accounting Standards are accounting principles applied in preparing and presenting government financial reports (Government Regulation No.71/2010). Government accounting standard represents cash toward accrual basis transition. Upon this standard, income, expenditure, and financing are recorded on a cash accounting basis, while asset, debt and equity are recorded on an accrual accounting basis. Thus, the government accounting standards are requirements that have legal force intended to improve the quality 
of government financial reporting. The government accounting standard stipulates two types of reporting: mandatory disclosure and voluntary disclosure. The former requires local government to disclose mandatory information in compliance with the applicable law, and the latter discloses only supplementary information. Conformity between the format of the preparation and submission of financial reports with the established accounting standards will reflect the quality, benefits, and capabilities of the financial statements themselves (Suhardjanto et al., 2010).

The current study ties well with an earlier research by (Setyaningrum \& Syafitri, 2012)., that measures compliance compared to disclosure. It employs assets, size and complexity of local government as the variables that are assumed to have an effect on local government financial reporting (Pratama et all, 2015). Complexity as proxied by legislature size and number od LGFR is used in this study to illustrate the number prioritized administrative matters in regional development (Khasanah \& Rahardjo, 2014).

The study is interesting because, first, similar studies have been conducted in private companies (Pradipta 2015; Dewi \& Yasa 2017; Nurkhin 2009; Sulisnaningrum \& Prabowo 2017; Wahyuningsih et al., 2016). Second, earlier studies on the extent of disclosure in local government financial reports revealed the results that remain inconsistent. (Setyaningrum \& Syafitri, 2012) found that local asset and legislature size have a significant effect on the degree of mandatory disclosure in LGFR. On the other hand, local government size and number of LGFR have no significant effect on the degree of mandatory disclosure in LGFR. Suhardjanto et al (2010) revealed different results as he found that it was only balance fund and educational background of the regional head that constitute the predictors of government compliance with mandatory disclosure. Based on earlier studies with inconsistent results, we attempt to conduct reassessment to determine what factors are more important for the degree of disclosure in local government financial reporting.

\section{Theoretical Framework}

\subsection{Agency Theory in Public Administration}

Government institutions are large and complex organizations and, therefore, they have to be managed properly. The management of public organizations, like that of private sector organizations, is carried out by a group of people authorized to do so. In the private sector shareholders are known as principals and authorized persons are called agents (Pratiwi \& Aryani, 2016).

Mulyani \& Wibowo (2017) maintain that in agency relationship there are two parties who will enter into an agreement or contract, namely the party that will give authority or power (the principal) and the party that will receive the authority (agent). In an organization, it is a vertical relationship, that is, between the superior (the principal) and the subordinate (the agent). The theory of the relationship between the two parties is popularly known as agency theory. Agency relationships are more often discussed in the context of businessoriented company management. The theory that describes principal-agent relationship rooted in, among others, economic, decision, sociological and organizational theories. This 
agency relationship gives rise to an asymmetric information problem where one party has substantially more information than the other.

\subsection{Local Government Financial Report}

According to Law No. 71 of 2010, local government financial records are ones that present government operational activities as well as the position of assets and liabilities that can be met by local governments. Among the components of government financial report are Notes to Financial Statements (NFS). Government Regulation no 71 of 2010 describes that Notes to Financial Statements include narrative explanations or details of the figures listed in the Budget Realization Report, financial position, and Cash Flow Statement. Notes to the Financial Statements are very important as a consideration in decision making to avoid misunderstandings that might occur between the presenter and the user of the reports. As stipulated in Law no 71 of 2010, Notes to the Financial Statements includes the following:

a. Disclosure of general information about the reporting and accounting entities;

b. Presentation of information about the fiscal or financial and macroeconomic policies;

c. Summarized presentation of financial target for the reporting year and the obstacles and constraints to achieving the target;

d. Presentation of information about the basis for financial report preparation and accounting policies chosen to be applied in transactions and other important events;

e. Presentation of details and description of each post on the front page of financial report;

f. Disclosure of information as required by Government Accounting Standard that has not been presented on the front page of financial report; and

g. Presentation of supplementary information for an unqualified presentation not presented on the front page of financial report.

\subsection{Disclosure of LGFR in NFS}

Disclosure, in case of financial reporting, can provide information and explanation of how the results of the activities of a business unit were achieved (Khasanah \& Rahardjo, 2014). In accordance with the statement in Government Regulation Number 24 of 2005, the financial reports are prepared to provide relevant information regarding the financial position and all transactions carried out by a reporting entity over one reporting period. The information provision is for the realization of transparency by providing open and fair financial information to the public. This was done because public has a right to know openly and comprehensively the responsible management of resources entrusted to the government and their adherence to the laws and regulations. Government Regulation no 71 of 2010 describes that Notes to Financial Statements include narrative explanations or details of the figures listed in the Budget Realization Report, financial position, and Cash Flow Statement.

\subsection{Characteristics}

Characteristics are special traits that correspond to certain typicality of one's character and performance that make a person's behavior can easily be noticed (Aziz, 2016). By characteristics here we mean certain typicalities inherent in local governments that differentiate them from one another (Suhardjanto \& Yulianingtyas, 2011). The 
characteristics of local government in this study are proxied by two variables - local assets and local government size.

\subsection{Local Government Assets}

Regional asset is illustrated by the performance of local governments in generating revenue, both from local revenue and other legitimate revenues. Local governments with considerable assets tend to provide good information and their financial reports will be presented comprehensively as the realization of their accountability (Ramdhani, 2016). Local government assets are proxied by Locally-Generated Revenue (LGR) because the latter is the only financial source that comes from managing local government resources (Artha et al., 2016).

\subsection{Local Government Size}

Size is an element in organizational structure (Patrick, 2007). The size of the government is proxied by the total assets, which are the resources used to carry out its operational activities (Maulana \& Handayani, 2015). Regional assets are part of the preparation of the initial regional balance sheet. The asset components in a financial position include fixed asset or current asset and inventory items. Regardless of the amount of assets included in the regional balance sheet, the management of regional assets is a very important component in the presentation of financial statements (Yusuf, 2010).

\subsection{Complexity}

By complexity we mean the state and factors in the internal and external environment that can affect the organization. Complexity in the government can mean a condition where various factors with diverse characteristics affect the government either directly or indirectly. The complexity of government is proxied by the number of Regional Working Unit (SKPDs) and the legislature size of local government (Martani \& Zaelani, 2011).

\subsection{Number of SKPDs}

The number of Regional Working Unit (SKPDs) is the number of organizational units that represent the functional differentiation of local governments in Indonesia. The government is divided into a number of different units, called SKPDs or OPDs. SKPDs have a position as elements that help regional heads (Suhardjanto et al., 2010).

\subsection{Legislature Size}

The size of the legislature is indicated by the number of legislators or the Regional Representative Council member (DPRD) (Kiswanto., 2016). DPRDs are the representative institutions of the local people in Indonesia that play an important role as an element of regional government administrators in the supervision of regional finances (Winarna \& Murni, 2007). DPRD members consist of members of political parties who are elected based on the general election results. In the regional government structure the DPRDs are located in three administrative regions; Provincial DPRD located in the provincial capital, Regencial 
DPRD in the regency capital, and municipal DPRD located in the municipal district (Sari et al., 2016).

\section{Hypothesis Development}

Local government with larger assets will bear higher oversight cost to meet the public demand for transparency compared to those with smaller assets. Local government assets indicate the prosperity level of the region. Locally-generated revenue is indicative of local government asset. It is one source of regional income that originates from its own region which can illustrate the level of regional autonomy (Santosa \& Rahayu, 2005).

According to Setyaningrum \& Syafitri (2012) local government asset is positively correlated with an increased degree of disclosure in financial reporting. Studies by (Hilmi \& Martani, 2012) and (Lasward et al., 2005) revealed that local assets are positively and significantly correlated with the degree of disclosure in regencial/municipal government financial reports. The larger the local asset, the higher the degree of disclosure in local government financial reports will be. This holds true because larger assets means larger resources available. Based on the findings of previous researches, our hypothesis would be as follows:

\section{$H_{1}$ : Local assets (PADs) have a positive effect on the degree of disclosure in LKPDs}

In organizations, asset management is a very important issue. Larger size will not necessarily encourage local governments to increase their degree of disclosure in their financial reports. Local governments with larger size tend to have more complex bureaucratic systems and, therefore, asset management supervision of local government will be more difficult compared to those with smaller size. This will increase the probability of inaccurate recording of assets in financial report disclosure. Larger assets will certainly require proper management and more items to be disclosed, especially those related to maintenance and management of asset. A study by (Budiarto \& Indarti, 2019) revealed that the size of local government has no significant effect. In contrast to the studies conducted by (Piotrowski \& Van Ryzin, 2007); (Serrano et al., 2009); (Qowi \& Prabowo, 2017); (Khasanah \& Rahardjo, 2014) argue that organizational size has a positive and significant effect on LGFR disclosure. Based on the findings of earlier researches, we formulate the following hypothesis:

\section{$\mathrm{H}_{2}$ : Local government size has a positive effect on LGFR disclosure}

RWUs are accounting entities which are obliged to record the transactions occurred in local government institutions. More complex government system requires higher degree of disclosure in government financial reports. The number of RWUs represents the number of matters that local government must deal with in regional development. The more things to be prioritized in a government system, the more complex the matter it has to deal with and, therefore, the higher the level of disclosure required (Maulana \& Handayani, 2015). (Suhardjanto \& Lesmana, 2010); (Khasanah \& Rahardjo, 2014) found that the number of RWUs has a positive and significant effect on the degree of disclosure in LGFR. In a similar vein (Mandasari, 2009) argued that more functional differentiation in local government 
means more ideas, information and innovations to disclose. Based on the findings of previous researches, our hypothesis would be as follows:

\section{$H_{3}$ : The number of $R W U$ s has a positive effect on the degree of disclosure in LGFRs}

Regional People's Representative Council (DPRD) serves as the legislature in this country. DPRDs form important part of local administration together with the local government. DPRD as the people's representative has a supervisory function, for example to keep the government running in accordance with the aspirations of the people and to oversee the reporting of financial information of the local government to be transparent and accountable. The larger number of DPRD members is expected to increase supervision of regional governments and, thereby, to improve LKPD disclosures. In this case, members of DPRD serve as the principals and local government as the agent. Supervision by the members of legislative body is intended to make sure that local governments fulfilled the tasks they have been entrusted with (Khasanah \& Rahardjo, 2014). (Suhardjanto \& Yulianingtyas, 2011); (Setyaningrum \& Syafitri, 2012) found that the number of DPRD members has a positive effect on the degree of disclosure.

\section{$H_{4}$ : Legislature Size of Local Government has a positive effect on LKPD disclosure}

\section{Research Methods}

The objects of this study are local governments at regencial/municipal level in the province of West Java. The units of analysis employed are the financial reports for the period 20142017 which have been audited by BPK RI and possess fairly complete data regarding the variables used in this study. There are 27 local governments in West Java province consisting of 9 municipal governments and 18 regencial governments. The study employed purposive sampling, which is a sampling technique based on the researcher's judgment and certain criteria (Sekaran \& Bougie, 2016). The criteria we used in this research study are as follows:

a. Financial reports of regency or municipal governments in West Java for the period 2014-2017 have been audited by the provincial representative of the Audit Board of the Republic of Indonesia (BPK).

b. Complete data for measuring the variables;

c. Providing four components of LKPD: Budget Realization Report, Balance Sheet, Cash Flow Report, and Notes to Financial Statements;

d. Providing the data on the number of SKPDs as accounting entities for the period 2014-2017 in the LKPD/Report of Internal Control System Inspection Results; and

e. Providing the data on the number of DPRD members for the period 2014-2017 in In Number of Regions of the respective Local government or as described in the official sites of the Local Government.

The data were collected directly from West Java Representative of the Audit Board of the Republic of Indonesia (BPK). The population of West Java province was chosen because this province had a lower degree of disclosure in LKPD. In fact, for the 2014-2015 fiscal year it had only a disclosure rate of 55\% (Naopal et al., 2017) 
compared to that of Banten Province with smaller government size yet reached a disclosure rate of $72 \%$ (Ramdhani, 2016).

The observation took 4 years to achieve better results because the previous researchers have analyzed their data for less than 4 years (Setyaningrum dan syafitri, 2012; khasanan dan Raharjo, 2014; Naopal et al., 2017). In this study we observed a population sample of 108 people. This figure complies with the rule of thumb that allow us to obtain better results if the number of samples employed ranges from 30 to 100 (Sekaran \& Bougie, 2016).

\section{Measurement of Variables}

As in earlier researches, the characteristics of local government are proxied by the assets and size of local government (Setyaningrum \& Syafitri, 2012), while the complexity is proxied by the number of SKPDs and legislature size (Martani \& Zaelani, 2011).

Table 1. Measurement of Variables

\begin{tabular}{lll}
\hline No. & \multicolumn{1}{c}{ Measurement of Variables } & \multicolumn{1}{c}{ Sources } \\
\hline $\begin{array}{l}\text { DISC }= \\
\text { Total items disclosed }\end{array}$ & (Suhardjanto \& Lesmana, 2010) \\
Total items to disclose & WEALTH $=$ Ln Total Pendapatan Asli Daerah & (Ramdhani, 2016) \\
3. & SIZE $=$ Ln Total Aset & (Hilmi \& Martani, 2012) \\
4. SKPD $=$ total number of SKPDs & (Suhardjanto \& Yulianingtyas, 2011) \\
5. $\quad$ U_LEG $=$ total member of DPRD & (Setyaningrum \& Syafitri, 2012) \\
\hline
\end{tabular}

Table 2. Research Sample

\begin{tabular}{|c|c|c|c|c|}
\hline Description & \multicolumn{2}{|c|}{ Total } & Results & \\
\hline Regencial LKPD & \multicolumn{2}{|c|}{$18 \times 4$ years } & \multicolumn{2}{|c|}{72} \\
\hline Municipal LKPD & \multicolumn{2}{|c|}{$9 \times 4$ years } & \multicolumn{2}{|c|}{36} \\
\hline & \multicolumn{2}{|c|}{ TOTAL SAMPEL } & \multicolumn{2}{|c|}{108} \\
\hline Variable & Min & Max & Mean & Std. Dev \\
\hline DISC & 33,33 & 87,88 & 48,8603 & 11,63564 \\
\hline WEALTH & 24,20 & 29,00 & 26,8649 & 0,88570 \\
\hline SIZE & 20,13 & 30,86 & 28,5501 & 1,38054 \\
\hline SKPD & 15 & 211 & 56,98 & 23,804 \\
\hline ULEG & 35 & 50 & 47,11 & 4,917 \\
\hline
\end{tabular}


Table 4. Hypotesis testing

\begin{tabular}{lccccc}
\hline \multicolumn{1}{c}{ Variable } & $\mathrm{B}$ & $\mathrm{t}$ & $\mathrm{S}$ Sig. & Exp \\
\hline WEALTH & 4,015 & 2,929 & $0,004^{*}$ & $\mathrm{H}_{1}$ : accepted & \\
SIZE & 2,553 & 3,273 & $0,001 *$ & $\mathrm{H}_{2}$ : accepted & \\
SKPD & 0,001 & 0,021 & 0,983 & $\mathrm{H}_{3}$ : rejected & \\
ULEG & 0,025 & 0,010 & 0,921 & $\mathrm{H}_{4}$ : rejected & \\
\hline F Value & 9,261 & & $0,000^{* *}$ & & \\
Adjusted R Square 0,236 & & & & & \\
** Sig < 1\%; * Sig < 5\% & & & &
\end{tabular}

\section{Results}

The results of descriptive statistic test (Table 3) indicate the mean value of 48,8603 ; minimum value of 33,33 and maximum value of 87,88 for disclosure. The mean values are 26,8649 for local government asset, 28,5501 for local government size, 56,98 for the number of SKPDs, and 48,8603 for legislature size. The mean values for the above 4 variables are greater than the standard deviation. From this we can conclude that the data analyzed have a good representativeness.

The result of analysis indicates that local government assets have a beta coefficient of 4,015 and p-value of 0,004 (significant). The results of this study suggest that local government assets have a significant effect on the degree of disclosure in LKPDs in West Java. This indicates that the value of local government assets greatly determines the local government financial reporting. According to (Pratama et al., 2015) PAD is a factor that supports macroeconomic performance. Positive growth rate drives investment that will simultaneously improve regional infrastructure. Good regional infrastructure and high level of investment in a region will increase the PAD. Assets may also be considered as one proof of good performance of local governments in their financial management. Local governments with higher PAD are more likely to give better financial reporting in order to gain public support for their current administration. Taking this into account, all government activities will run smoothly and the public have access to regional asset management accountability. Our results corroborate those of previous study (Setyaningrum \& Syafitri, 2012) suggesting that larger assets owned by local governments will put pressure on them to provide greater degree of disclosure. Larger asset of local government is inseparable from an increasing level of public participation in paying taxes and from regional levies. Therefore, local government would be encouraged to provide more complete disclosure in their financial reports in order to become transparent and accountable (Lasward et al., 2008).

The analysis reveals that local government size has a beta coefficient of 2,553 with a pvalue of 0,001 (significant). The results of this study prove that local government size has a significant effect on the degree of disclosure in LKPDs in West Java. This indicates that local government size highly determines the financial reporting of local governments. Local governments with larger size are more likely to have more complex financial management and, therefore, supervision of local government will be stricter (Pratama et al.,2015; Sari et al., 2016). Based on stewardship theory, local governments with larger size, as proxied by 
their total assets, bear greater responsibility in financial statement disclosure (Khasanah \& Rahardjo, 2014).

Our analysis shows that the number of SKPDs has a beta coefficient of 0,001 with a pvalue of 0,849 (not significant). The results of the study reveals that the number of SKPDS has no significant effect on the degree of disclosure in local government financial reports. This holds true because the larger the number of SKPDs, the more complicated the coordination between them will become. Such a condition can lead to potentially innacurate recordings. Moreover, the management of local government investment, especially in financial aid such as revolving fund, requires coordination between SKPDs because each of them bears differentiated responsibilities for cash withdrawal, disbursement, and supervision of the actual implementation (Suharjanto and Yulianingtyas, 2011; Setyaningrum and Syafitri 2012). This put the government in an increasingly difficult position to oversee the SKPDs' compliance to mandatory disclosure rules (Suhardjanto et al., 2010).

Our analysis indicates that local government size has a beta coefficient of 0,025 and a p-value of 0,921 (not significant). This reveals that legislature size has no sifnificant effect on the degree of disclosure in LKPDs in West Java. Our results corroborate those of (Khasanah \& Rahardjo, 2014) while, theoretically speaking, the larger the size of legislature, the higher the level of supervision would have been. This will have a positive effect on financial reports. However, the supervision is not necessarily that high because quality supersedes quantity. The large number of DPRD members doesn't mean that they serve better functions and roles, and therefore their supervision may not function optimally. The many issues about corruption committed by DPRD members can also be a reason for the decline in government performance which will then have an impact on the declining degree of disclosure in financial reports.

\section{Conclusion}

Based on the results presented above we may conclude, firstly, that the characteristics as proxied by local government assets and size have a significant effect on the degree of disclosure. Secondly, the complexities as proxied by the number SKPDs and legislature size have no significant effect on the degree of disclosure. Therefore, we can further conclude that it would be better if the the comparison is between the characteristics and the local government complexities with respect to the disclosure in local financial reports. The results of this study also indicate that the average degree of disclosure in local government financial reports (LKPDs) at the regencial or municipal level in West Java over the period 2014-2017 amounted to $49 \%$.

\section{Limitations and Suggestions}

The limitation of this study are, first, we use only data from local government financial reports in West Java over the 4-year period (2014-2017). Future researches are expected to increase the sampel and the period of study because the number of sample affects the results of study (Alharbi \& Drew, 2014). Second, the characteristics and complexities of local government employed in this study explain only small part of the factors affecting the 
degree of disclosure in local government financial reports. This means that there are many other factors such as the administrative period of local government, job specialization, financial independence ratio, and intergovernmental revenue that explain the degree of disclosure in the local government financial reports (Setyaningrum \& Syafitri, 2012).

\section{REFERENCES}

Alharbi, S., \& S, Drew. (2014). Using the tecnologi acceptance model in understanding academics behavioral intention to use learning managemen system. internatonal jurnal of advanced computer science and applications, 5(1), 143-155.

Artha, R. D., Basuki, P., \& Alamsyah, M. (2016). Pengaruh karakteristik pemerintah daerah dan temuan audit BPK terhadap kinerja penyelenggaraan pemerintahan daerah (Studi empiris pada pemerintah kabupaten/kota di provinsi NTB). InFestasi, 11(2), 214229.

Aziz, A. (2016). Pengaruh Karakteristik Pemerintah Daerah Terhadap Kinerja Keuangan Pemerintah Daerah. (Studi Pada Pemerintah Daerah Kabupaten/Kota Di Jawa Timur). Universitas Islam Majapahit Mojokerto. Vol XI, No.1

Budiarto, D. S., \& Indarti, L. (2019). Apakah Karakteristik Pemerintah Daerah Berpengaruh Pada Pengungkapan Laporan Keuangan Pemerintah Daerah? Riset Pada Kabupaten Di Jawa Tengah. Jurnal Akuntansi Bisnis, 12(1).

Dewi, I. A. P. O. Y., \& G. W, Yasa. (2017). Pengaruh ukuran perusahaan, profitabilitas, tipe industri dan kinerja lingkungan terhadap environmental disclosure. E-Jurnal Akuntansi: 2362-2391

Hilmi, A. Z., \& D, Martani. (2012). alisis faktor-faktor yang memengaruhi tingkat pengungkapan laporan keuangan pemerinth provinsi. Simposium Nasional Akuntansi, 15, 13-20.

Khasanah, N. L., \& Rahardjo, S. N. (2014). Pengaruh karakteristik, kompleksitas, dan temuan audit terhadap tingkat pengungkapan laporan keuangan pemerintah daerah. Diponegoro Journal of Accounting, 3(2), 864-874.

Kiswanto., N. N. (2016). pengaruh Karakteristik Pemerintah Daerah Temuan Audit BPK Terhadap Kinerja Keuangan Pemerintah Daerah. Accounting Analisis Journal. Universitas Negeri Semarang. 5(1)

Laswad, F., Fisher, R., \& Oyelere, P. (2005). Determinants of voluntary Internet financial reporting by local government authorities. Journal of Accounting and Public Policy, 24(2), 101-121.

Mandasari, P. (2009). Practices of Mandatory Disclosure Compliance in Indonesian Local Government. Tesis Master. Universitas Sebelas Maret.

Mardiasmo. (2016). Analisis laporan keuangan pemerintah daerah. Yogyakarta. STIM YKPN.

Martani, D., \& Zaelani, F. (2011). Pengaruh Ukuran, Pertumbuhan, dan Kompleksitas terhadap Pengendalian Intern Pemerintah Daerah (Studi Kasus di Indonesia). Simposium Nasional Akuntansi.

Maulana, C., \& Handayani, B. D. (2015). Pengaruh Karakteristik, Kompleksitas Pemerintahan dan Temuan Audit Terhadap Tingkat Pengungkapan Wajib LKPD. Accounting Analysis Journal, 4(4).

Mulyani, S., \& H Wibowo. (2017). Pengaruh belanja modal, ukuran pemerintah daerah intergovenmental revenue dan pendapatan asli daerah terhadap kinerja keuangan 
(Kabupaten/Kota di Provinsi Jawa Tengah, tahun 2012-2015). Kompartemen: Jurnal Ilmiah Akuntansi, 15(1): 1-10.

Naopal, F., Rahayu, S., \& Yudowati, S. P. (2017). Pengaruh Karaktersitik Daerah, Jumlah Penduduk, Temuan Audit, dan Opini Audit terhadap Pengungkapan Laporan Keuangan Pemerintah Daerah. Assets: Jurnal Ekonomi, Manajemen, dan Akuntansi, $7(1), 56-68$.

Nurkhin, A. (2009). Corporate governance dan profitabilitas; Pengaruhnya terhadap pengunkapan tanggungjawab sosial perusahaan (Studi Empiris pada perusahaan yang telah tercatat di Bursa Efek Indonesia). Tesis, program pascasarjana universitas diponegoro. 1-97

Patrick, P. A. (2007). The determinants of organizational innovativeness: The adoption of GASB 34 in Pennsylvania local government. Pennsylvania State University.

Piotrowski, S. J., \& Van Ryzin, G. G. (2007). Citizen attitudes toward transparency in local government. The American Review of Public Administration, 37(3), 306-323.

Pradipta, F. C. (2015). Kualitas Laporan Keuangan Pemerintah Daerah: faktor yang mempengaruhi dan implikasi kebijakan (Studi pada SKPD pemerintah provinsi Jawa Tengah). Jurnal Bisnis dan Ekonomi, 22(2):188-200.

Pratama, K. A. D., D. N. S. Werastuti, dan E. Sujana. (2015). Pengaruh Kompleksitas Daerah, Ukuran Pemerintah Daerah, Kekayaaan Daerh, Dan Belanja Daerah Terhadap Pelaporan Keuangan Pemerintah Daerah. e-Jurnal S1 Ak Universitas Pendidikan Ganesha. 3(1), 1-12.

Pratiwi, R., \& Aryani, Y. A. (2016). Pengaruh Karakteristik Pemerintah Daerah, Kepala Daerah, Tindak Lanjut Temuan Audit terhadap Opini. Jurnal Akuntansi, 20(2), 167189.

Qowi, R., \& Prabowo, T. J. W. (2017). Pengaruh karakteristik pemerintah daerah dan temuan pemeriksaan BPK terhadap kinerja pemerintah daerah kabupaten/kota di Indonesia tahun anggaran 2012. Diponegoro Journal of Accounting, 6(1), 298-310.

Ramdhani, D. (2016). Analisis Faktor-Faktor Yang Mempengaruhi Tingkat Pengungkapan Laporan Keuangan Pemerintah Daerah Di Propinsi Banten. Jurnal Riset Akuntansi Terpadu, 9(2).

Santosa, P. B., \& Rahayu, R. P. (2005). Analisis Pendapatan Asli Daerah (PAD) dan Faktorfaktor yang mempengaruhinya dalam upaya pelaksanaan otonomi daerah di Kabupaten Kediri. Jurnal Dinamika Pembangunan (JDP), 2(Nomor 1), 9-18.

Sari, I. P., Agusti, R., \& Rofika, R. (2016). Pengaruh Ukuran Pemerintah Daerah, PAD, Leverage, Dana Perimbangan dan Ukuran Legislatif terhadap Kinerja Keuangan Pemerintah Daerah (Studi pada Kab/kota Pulau Sumatra). Jurnal Online Mahasiswa Fakultas Ekonomi Universitas Riau, 3(1), 679-692.

Sekaran, U., \& Bougie, R. (2016). Research methods for business: A skill building approach: John Wiley \& Sons.

Serrano-Cinca, C., Rueda-Tomás, M., \& Portillo-Tarragona, P. (2009). Factors influencing e-disclosure in local public administrations. Environment and planning $C$ : Government and Policy, 27(2), 355-378.

Setyaningrum, D., \& Syafitri, F. (2012). Analisis pengaruh karakteristik pemerintah daerah terhadap tingkat pengungkapan laporan keuangan. Jurnal Akuntansi dan Keuangan Indonesia, 9(2), 154-170.

Suhardjanto, D., \& Lesmana, S. I. (2010). Pengaruh karakteristik pemerintah daerah terhadap tingkat pengungkapan wajib di Indonesia. PRESTASI, 6(2).

Suhardjanto, D., \& Yulianingtyas, R. R. (2011). Pengaruh karakteristik pemerintah daerah terhadap kepatuhan pengungkapan wajib dalam laporan keuangan pemerintah daerah 
(Studi empiris pada kabupaten/kota di Indonesia). Jurnal Akuntansi dan Auditing, 8(1), 30-42.

Suhardjanto, D., Rusmin, Mandasari, P.,Brown, A. (2010). Mandatory Disclosure Compliance and Local Government Characteristics: Evidence from Indonesian Municipalities. Penelitian Hibah Publikasi Internasional, LP2M UNS.

Sulisnaningrum, E., \& B. H, Prabowo. (2017). Pengaruh faktor-faktor keuangan terhadap kelengkapan pengungkapan laporan keuangan berbasis SAK Etap pada koperasi wanita kota Malang. Koordinasi Perguruan Tinggi Swasta (KOPERTIS) Wilayah VII, 10(2): 5358.

Undang-Undang Republik Indonesia Nomor 71 Tahun 2010 Lampiran I.01 Pernyataan 01 Tentang Penyajian Laporan Keuangan Tentang Standar Akuntansi Pemerintahan.

Wahyuningsih, W., R, Arifati., \& K, Raharjo. (2016). Pengaruh likuiditas, leverage, profitabilitas, porsi saham publik, ukuran perusahaan dan umur perusahaan terhadap kelengkapan pengungkapan laporan keuangan pada perusahaan manufaktur yang terdaftar di Bursa Efek Indonesia dengan periode penelitian tahun 2. Journal of Accounting, 2(2): 1-12.

Winarna, J., \& Murni, S. (2007). Pengaruh personal background, political background dan pengetahuan dewan tentang anggaran terhadap peran DPRD dalam pengawasan keuangan daerah (Studi Kasus Di Karesidenan Surakarta dan Daerah Istimewa Yogyakarta Tahun 2006). Jurnal Bisnis dan Akuntansi, 9(2), 136-152.

Yusuf, M. (2010). Delapan Langkah Pengelolaan Aset Daerah Menuju Pengelolaan Keuangan Daerah Terbaik. Salemba Empat, Yogyakarta.

www.bappeda. Kutaikartanegarakab.go.id

www. Wikipedia.com 2009

www. Wikipedia.com 2010 